\title{
Design of a Novel Theranostic Nanomedicine (III): Synthesis and Physicochemical Properties of Tumor-Targeting Cisplatin Conjugated to a Hydrophilic Polyphosphazene
}

This article was published in the following Dove Press journal:

International Journal of Nanomedicine

\section{Basavaraj R Patil \\ Su Yeon Kang ${ }^{2}$ \\ Da Hee Jung ${ }^{2}$ \\ Prakash G Avaji \\ Yong Joo Jun' \\ Hwa Jeong Lee ${ }^{2}$ \\ Youn Soo Sohn'}

'C \& Pharm, Ewha Womans University, Seoul 03760, Republic of Korea; ${ }^{2}$ Graduate School of Pharmaceutical Sciences, Ewha Womans University, Seoul 03760, Republic of Korea
Correspondence: Youn Soo Sohn

C \& Pharm, Ewha Womans University,

Room 304, University-Industry

Cooperation Building, 52 Ewhayeodae-

Gil, Seodaemun-Gu, Seoul 03760,

Republic of Korea

Tel +82707008 2120

Fax +8223628813

Email yssohn@ewha.ac.kr

Hwa Jeong Lee

Graduate School of Pharmaceutical

Sciences, Ewha Womans University, 52

Ewhayeodae-Gil, Seodaemun-Gu, Seoul

03760, Republic of Korea

Tel +82 232773409

Fax +82 23277285 I

Email hwalee@ewha.ac.kr
Purpose: A new theranostic nanomedicine involving anticancer-active cisplatin moiety was designed to study its tumor-targeting properties as well as its drug efficacy and toxicity.

Methods: A cisplatin carrier polymer was prepared by grafting equimolar polyethylene glycol of a molecular weight of 550 (PEG550) and aminoethanol to the poly(dichlorophosphazene) backbone. Cisplatin was conjugated to the carrier polymer using cis-aconitic acid as a linker.

Results: The cisplatin-loaded polyphosphazene, named "Polycisplatin" was found to be amphiphilic in aqueous solution and self-assembled into nanoparticles with an average particle size of $18.6 \mathrm{~nm}$ in diameter. The time-dependent organ distribution study of Cy5.5-labeled Polycisplatin in the A549tumor-bearing mice exhibited a high tumor selectivity of Polycisplatin by EPR effect despite the relatively small particle size. In order to compare the in vivo efficacy of Polycisplatin and cisplatin, their xenograft trials were performed using nude mice against the human gastric cell line MKN-28. Polycisplatin exhibited slightly less tumor suppression effect compared with cisplatin at the same dose of $1.95 \mathrm{mg} \mathrm{Pt} / \mathrm{kg}$, which is the maximum tolerate dose of cisplatin, but at the higher double dose of $3.9 \mathrm{mg} \mathrm{Pt} / \mathrm{kg}$, Polycisplatin exhibited a little better efficacy than cisplatin. Furthermore, mice treated with cisplatin at the dose of $1.95 \mathrm{mg}$ Pt $/ \mathrm{kg}$ exhibited severe body weight decrease by about $25 \%$, while mice treated with Polycisplatin did not show serious body weight decrease even at its double dose of $3.9 \mathrm{mg} \mathrm{Pt} / \mathrm{kg}$. Furthermore, kidney indicators including kidney index, BUN, and creatinine values measured displayed that Polycisplatin is much less nephrotoxic than cisplatin.

Conclusion: Nanoparticular Polycisplatin was successfully prepared by conjugating cisplatin to a hydrophilic polyphosphazene carrier polymer using the acid-cleavable cis-aconitic acid. Polycisplatin nanoparticles exhibit excellent tumor-targeting properties by EPR effect. The xenograft trials exhibited excellent antitumor efficacy and reduced systemic toxicity of Polycisplatin.

Keywords: cisplatin, polyphosphazene, platinum drug, drug delivery, nanomedicine

\section{Introduction}

Cisplatin (cis-diamminedichloroplatinum(II)) is one of the most widely used first-line chemotherapeutic agents for a broad range of cancers. Cisplatin continues to be in widespread clinical use for various solid tumors such as ovarian, testicular, bladder, head and neck, and non-small cell lung cancers ${ }^{1,2}$ but its usefulness is limited due to its high toxicity and various side effects along with its cross-resistance. ${ }^{3,4}$ Therefore, recently versatile efforts have been focused to search an ideal prodrug of cisplatin by 
using a variety of drug delivery systems. For example, Kataoka group ${ }^{5}$ incorporated cisplatin into polymeric micelles formed from a block copolymer composed of polyethylene glycol and poly(glutamic acid) (NC-6004), and Shen et al $^{6}$ prepared a cisplatin-loaded nanoparticles from PDEA (poly[2-( $N, N$-diethylamino) ethyl methacrylate]. There are many other attempts to deliver cisplatin by using polymeric micelles, ${ }^{7,8}$ microspheres or nanoparticles $^{9-13}$ which are designed to take advantage of the enhanced permeability and retention (EPR) effect to target the tumor tissue for efficient delivery of the anticancer agent. Among the above several attempts, the long-circulating polymeric micelles NC-6004, liposomal cisplatin formulations SPI-077 and L-NDDP entered clinical trials. However, it seems clear from their animal experiments that we need to improve further drug efficacy by more efficient tumor targeting and rapid drug releasing in tumor tissue along with overcoming its drug resistance.

We have designed and prepared a new nanoparticular polyphosphazene-cisplatin conjugate by linking cisplatin to a hydrophilic polyphosphazene carrier polymer using acid-cleavable cis-aconitic anhydride as a linker ${ }^{14,15}$ to improve drug availability in tumor tissue and minimize drug toxicity. Furthermore, such polymeric cisplatin is expected to overcome cisplatin cross-resistance by endocytosis mechanism, ${ }^{16}$ but we could not test the crossresistance of our Polycisplatin compound in the present study because of domestic unavailability of the cisplatinresistant cell lines at the present time.

\section{Materials and Methods Materials}

Methoxy poly(ethylene glycol) with a number average molecular weight of 550 (MPEG550), ethanolamine, sodium hydride, silver sulfate, sodium diethyldithiocarbamate, phosphonitrilic chloride trimer and aluminium chloride were procured from Sigma-Aldrich. Anhydrous tetrahydrofuran was procured from Merck. Potassium tetrachloroplatinate(II) (Kojima Chemicals), potassium iodide (Junsei Chemicals) and ammonium hydroxide (Daejung Chemicals) were used as received. Phosphonitrilic chloride trimer was purified by sublimation. cis-Diamminediaquoplatinum(II) sulfate was prepared from cis-diamminediiodoplatinum(II) as reported previously. ${ }^{17}$ Poly(dichlorophosphazene) was prepared by thermal polymerization of phosphonitrilic chloride trimer in the presence of $\mathrm{AlCl}_{3}$ catalyst as detailed in our earlier publication. ${ }^{18}$ Human alveolar basal epithelial carcinoma cell line (A549) and human gastric cancer cell line (MKN28) were purchased from Korean Cell Line Bank (Seoul, Korea). BALB/c nude mice (male, 5 weeks, $20 \pm 2 \mathrm{~g}$ ) and ICR mice (male, 5 weeks, $20 \pm 2 \mathrm{~g}$ ) were purchased from Orient Bio Inc. (Gyeonggi-do, Korea)

\section{Methods}

${ }^{1} \mathrm{H}$ and proton decoupled ${ }^{31} \mathrm{P}$, NMR spectra were measured using Varian $500 \mathrm{MHz}$ NMR spectrophotometer (Varian, Inc., Palo Alto, CA, USA). Phosphoric acid was the internal standard for ${ }^{31} \mathrm{P}$, NMR spectra. The infrared spectra were recorded on the PerkinElmer Frontier FT-IR spectrometer. The particle size distribution of the polyphosphazene carrier polymer and Polycisplatin were measured by the dynamic light scattering (DLS) method using a Malvern Zetasizer Nano-ZS analyzer (Malvern Instruments, UK). The Pt content of Polycisplatin was determined by Agilent 1260 Infinity HPLC-UV system using diethyldithiocarbamate (DDTC) as the complexing agent according to the literature method. ${ }^{19}$ The TEM image of Polycisplatin was measured in aqueous solution (20 mg/mL) using $200 \mathrm{kV}$ Tecnai F20 (FEI, Eindhoven, the Netherlands).

\section{Synthesis of Polycisplatin [NP(MPEG550)(AE)(AA)Pt $\left.\left(\mathrm{NH}_{3}\right)_{2}\right]_{\mathrm{n}}$}

Polyphosphazene carrier polymer, [NP(MPEG550)(AE) $]_{\mathrm{n}}$, was prepared by the procedure described in our previous report. $^{20}$ The solution of $[\mathrm{NP}(\mathrm{MPEG} 550)(\mathrm{AE})]_{\mathrm{n}}(1.0 \mathrm{~g}, 1.5$ mmol) in water was cooled to $0^{\circ} \mathrm{C}$ and cis-aconitic acid anhydride (AA) (0.234 g, $1.5 \mathrm{mmol})$ was slowly added to this solution. Aqueous $\mathrm{NaOH}$ solution was added dropwise to maintain this reaction mixture at $\mathrm{pH} 8.0$. The reaction mixture was stirred for $5 \mathrm{~h}$ at $0-4^{\circ} \mathrm{C}$.

The solution of $\left[\left(\mathrm{NH}_{3}\right)_{2}\left(\mathrm{H}_{2} \mathrm{O}\right)_{2} \mathrm{Pt}\right] \mathrm{SO}_{4}(0.272 \mathrm{~g}, 0.75$ mmol) dissolved in $25 \mathrm{~mL}$ of distilled water was added dropwise with stirring to the carrier polymer $[\mathrm{NP}(\mathrm{MPEG} 550)(\mathrm{AE})(\mathrm{AA})]_{\mathrm{n}}(1.5 \mathrm{mmol})$ solution in water. The $\mathrm{pH}$ of the solution was maintained above 7 throughout the reaction course. This reaction mixture was stirred for $2 \mathrm{~h}$ at RT and then dialyzed in distilled water using a cellulose membrane (MWCO: $10 \mathrm{kDa}$ ). The dialyzed solution was freezedried finally to obtain the cisplatin-loaded polyphosphazene named "Polycisplatin". Yield: 70\%. FTIR $\left(\mathrm{cm}^{-1}\right): 2866.4 \mathrm{~s}$, $1562.2 \mathrm{~m}, 1453 \mathrm{w}, 1349.1 \mathrm{~m}, 1290.3 \mathrm{~m}, 1198.8 \mathrm{w}, 1097.6 \mathrm{sh}$, $1039.8 \mathrm{~m}, 947.5 \mathrm{~m}, 847 \mathrm{~m}, 614.9 \mathrm{~m}, 523.5 \mathrm{~s}, 493.3 \mathrm{~m}$. The platinum content $(4.91 \%)$ of Polycisplatin was determined by modified HPLC-UV method detailed in the literature. ${ }^{19}$ 
Briefly, a known amount of Polycisplatin was dissolved in $0.5 \mathrm{M} \mathrm{HCl}$ solution and stirred so as to cleave the AA-Pt bond and release the cisplatin. The cisplatin was then treated with $100 \mu \mathrm{L}$ of $(10 \%)$ DDTC in $0.1 \mathrm{~N} \mathrm{NaOH}$ and incubated in a water bath at $37^{\circ} \mathrm{C}$ for $30 \mathrm{~min}$. The resultant Pt-DDTC complex formed was extracted with chloroform by vigorous vortex of the solution mixture, and then the chloroform layer collected was evaporated under vacuum. The resultant residue was reconstituted with $20 \mu \mathrm{L}$ of acetonitrile and the reconstituted sample was injected into the HPLC for Pt analysis on an Agilent Eclipse plus C18 column $(5 \mu \mathrm{m}, 4.6 \times 150 \mathrm{~mm})$ maintained at ambient temperature $\left(25^{\circ} \mathrm{C}\right)$. The water: methanol: acetonitrile (30:40:30 v/v/v) mobile phase was employed with a fixed flow rate of $1.0 \mathrm{~mL} / \mathrm{min}$. Eluent was monitored using a UV/VIS detector set at $254 \mathrm{~nm}$. The amount of $\mathrm{Pt}$ loaded on the carrier polymer (mass/mass \%) was found to be $4.91 \%$.

\section{Ex vivo Imaging Study of Cy5.5-Labeled Polycisplatin}

BALB/C nude mice (5 weeks old), weighing between 18 and $20 \mathrm{~g}$, were housed in a specific pathogen-free room kept at a temperature of $23^{\circ} \mathrm{C} \pm 3^{\circ} \mathrm{C}$ and relative humidity of $50 \% \pm 5 \%$. All mice were accessible to sterilized standard chow diet and water. All animal study protocols were reviewed and approved by the Institutional Animal Care and Use Committee (IACUC number 16-062) of Ewha Womans University, Seoul, Korea. Animal care was performed according to the Institute for Laboratory Animal Research (ILAR) guidelines.

Human alveolar basal epithelial carcinoma cell line (A549) was grown in Roswell Park Memorial Institute MI 1640 (RPMI 1640) media containing 10\% fetal bovine serum at $37^{\circ} \mathrm{C}$ in a humidified $5 \% \mathrm{CO}_{2}$ atmosphere. The A549 cells were suspended in serum-free RPMI 1640 media and inoculated subcutaneously at a density of $5 \times$ $10^{6}$ cells per $150 \mu \mathrm{L}$ into the right flank region of each mouse. After 2 weeks, when the tumor was grown to 200-250 $\mathrm{mm}^{3}$, the Cy5.5-labeled Polycisplatin was injected intravenously into the tail vein of the tumorbearing mice. Cy5.5-labeled Polycisplatin was prepared following the same procedure for Cy5.5-labeled Polyplatin. ${ }^{20}$ Briefly, some terminal amine groups of $\mathrm{AE}$ of the carrier polymer $[\mathrm{NP}(\mathrm{MPEG} 550)(\mathrm{AE})(\mathrm{AA})]_{\mathrm{n}}$ are required for $\mathrm{Cy} 5.5$ labeling and imaging study. Coupling agent HBTU ( $\left.7 \mathrm{mg}, 1.8 \times 10^{-3} \mathrm{mmol}\right)$ and triethylamine $(0.5 \mathrm{~mL})$ were added to a suspension of Polycisplatin
(63 mg, $0.06 \mathrm{mmol}$ ) and Cy5.5 mono acid (1 mg, $\left.9.69 \times 10^{-4} \mathrm{mmol}\right)$ in anhydrous DMF $(5 \mathrm{~mL})$ and the reaction mixture was stirred at room temperature for 18 hrs. The reaction mixture was diluted with $50 \mathrm{~mL}$ of ethanol and then centrifuged at 4,000 rpm in Vivaspin Polyethersulfone Ultrafiltration Spin Columns (MWCO: $50 \mathrm{kDa}$ ) and finally washed with water several times.

The animals were sacrificed at 12, 24 and $48 \mathrm{~h}$ after injection, and their liver, heart, lung, kidney, spleen, tumor, and muscle (from the left flank region) were harvested and weighed. The fluorescence intensity of each organ was measured immediately after sacrifice. The fluorescence images of harvested organs and tumors were obtained using IVIS ${ }^{\circledR}$ Lumina Series III In vivo Imaging System (Perkin Elmer, CLS136334). To observe the fluorescence image, Living Image 4.4 program was used.

\section{In vitro Drug Release Study}

The time-dependent release of the cisplatin moiety $\left(\mathrm{NH}_{3}\right)_{2}$ $\mathrm{Pt}$ (II) from Polycisplatin in different buffer solutions of $\mathrm{pH}$ 5.4 and 7.4 was examined at $37^{\circ} \mathrm{C}$ under sink condition. Each $5 \mathrm{~mL}$ of the sample solutions $(2 \mathrm{mg} / \mathrm{mL})$ was placed in a cellulose tubing membrane with MWCO of 3,000 Da and suspended in $50 \mathrm{~mL}$ of respective buffer solutions under gentle stirring at $100 \mathrm{rpm}$. From each sample solution, $1 \mathrm{~mL}$ was withdrawn from the dialysate at predetermined time intervals over 14 days. Inductively coupled plasma mass spectrometry was employed to determine the amount of released platinum.

\section{In vivo Nude Mouse Xenograft Trial}

The in vivo antitumor efficacy of Polycisplatin and cisplatin (as a reference) was evaluated against a gastric tumor cell line MKN-28 using BALB/C nude mice (5 weeks old, 18-20 g). Animals were adapted under controlled temperature and humidity for 1 week prior to the experiments. MKN-28 cells were cultured in RPMI 1640 media containing $10 \%$ fetal bovine serum and $1 \%$ antibiotic-antimycotic agent (cell culture media) at $37^{\circ} \mathrm{C}$ in a humidified $5 \% \mathrm{CO}_{2}$ atmosphere and were detached with $0.25 \%$ trypsin-EDTA solution. The assembled cells were centrifuged in cell culture media for $2 \mathrm{~min}$.

The concentration of cells in media was calculated from the number of cells counted using a hemocytometer (catalog number 0650030; Paul Marienfeld, LaudaKönigshofen, Germany). The tumor cells were suspended in serum-free RPMI 1640 media at a density of $5 \times 10^{6}$ cells in $150 \mu \mathrm{L}$ of media and inoculated subcutaneously 
into the right flank region of each mouse. When the average tumor volume reached about $100-150 \mathrm{~mm}^{3}$, the test drugs or normal saline as a control were injected intravenously via the tail vein of the mice according to a triple injection regimen on days 1,5 , and 9. In order to compare the antitumor efficacy of Polycisplatin and cisplatin, tumor size and weights of the mice were measured every 3 or 4 days. The mice were sacrificed on the 35 th day from the first injection.

\section{Estimation of Acute Toxicity of Polycisplatin}

ICR mice (5 weeks old) weighing 20-23 g were subjected to a study to measure the lethal dose $\left(\mathrm{LD}_{50}\right)$ of Polycisplatin to compare with that of cisplatin. The mice were randomly divided into six groups with four mice each. Different doses of Polycisplatin based on its platinum content (5, 10, 15 and $20 \mathrm{mg} \mathrm{Pt} / \mathrm{kg}$ ) and 6.5 and $13 \mathrm{mg} \mathrm{Pt} / \mathrm{kg}$ of cisplatin for comparison were intravenously injected. Also, one group of four mice was intravenously injected with saline as a control. After injection, the changes in body weight and the survival rate were daily recorded over a period of 2 weeks. The survival rate of mice was calculated as (number of live mice/total number of mice treated) $\times 100 \%$. The $\mathrm{LD}_{50}$ values of the Polycisplatin and cisplatin were calculated according to the Organisation for Economic Cooperation and Development guideline 425 .

\section{Kidney Toxicity Test}

Using the kidney and plasma samples obtained from above in vivo xenograft experiments, the kidney indicators such as kidney index, BUN and creatinine values were estimated. The kidney index was calculated in the following Equation:

$$
\text { kidney index }=\left(\frac{\text { Kidney weight }}{\text { Body weight }}\right)
$$

BUN values were estimated using BUN kit (Quanti Chorm $^{\mathrm{TM}}$ Urea Assay Kit, BioAssay systems). Each of plasma samples, distilled water (blank), and $5 \mu \mathrm{L}$ of standard solution were mixed in 96-well plates in duplicate. Two hundred microliters of working reagent was added to each well. After tapping and incubation for 20 mins, optical density was measured at $520 \mathrm{~nm}$. We calculated BUN using the following equation:

$$
\mathrm{BUN}=\frac{\left(\frac{\mathrm{OD}_{\text {SAMPLE }}-\mathrm{OD}_{\text {BLANK }}}{\text { OD }_{\text {STANDARD }}-\mathrm{OD}_{\text {BLANK }}}\right) \times \mathrm{n} \times[\mathrm{STD}]}{2.14}(\mathrm{mg} / \mathrm{dL})
$$

Creatinine values were obtained using Creatinine kit (QuantiChorm $^{\mathrm{TM}}$ Creatinine Assay Kit, BioAssay systems). Each of samples (plasma) and $30 \mu \mathrm{L}$ of standard solution were mixed in 96-well plates in duplicate. Two hundred microliters of working reagent combined $\mathrm{A}$ and B to each well. After tapping, optical density of each sample was measured using Elisa Reader (Multiskan GO, Thermo Scientific) at $510 \mathrm{~nm}$ at 0 and 5 mins. We have calculated creatinine values using the following equation:

$$
\begin{aligned}
\text { Creatinine }= & \left(\frac{\text { OD }_{\text {SAMPLE5 }}-\text { OD }_{\text {SAMPLE0 }}}{\text { OD }_{\text {STANDARD5 }}-\text { OD }_{\text {STANDARD0 }}}\right) \\
& \times[\mathrm{STD}](\mathrm{mg} / \mathrm{dL})
\end{aligned}
$$

\section{Results and Discussion Synthesis and Physicochemical Properties of Polycisplatin}

The anticancer-active cisplatin moiety, $\left(\mathrm{NH}_{3}\right)_{2} \mathrm{Pt}(\mathrm{II})$ was successfully conjugated to a polyphosphazene carrier

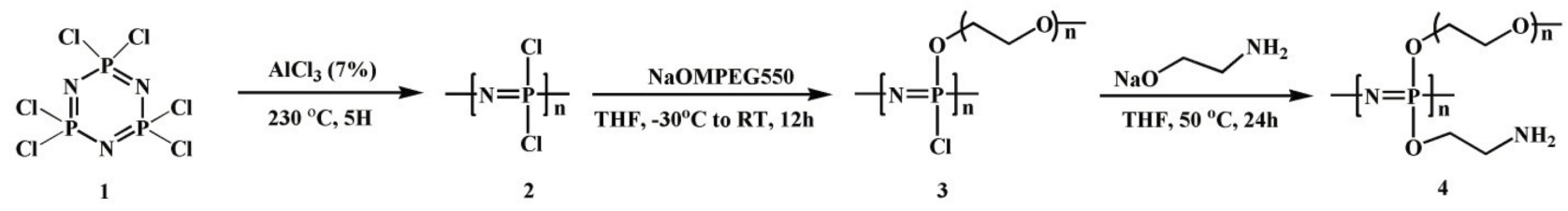

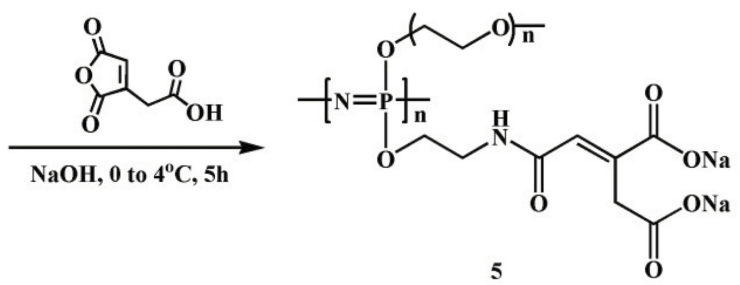<smiles>CN(C)[N+](C)(OCCNC(=O)C=C1CC(=O)O[PH](N)(N)OC1=O)OCCOCCO</smiles>

Scheme I Synthetic pathway for the polyphosphazene carrier polymer and its cisplatin conjugate, Polycisplatin. 
polymer using the cis-aconitic acid anhydride as a linker as shown in the following reaction Scheme 1, which is described in detail in the experimental section.

The final product of Polycisplatin (6) was obtained as a light yellow gel highly soluble in water and polar organic solvents such as ethanol, acetonitrile, methylene chloride, etc. In order to estimate its tumor-targeting properties by EPR (enhanced permeability and retention) effect, ${ }^{21,22}$ we have performed its morphology study in aqueous solution. We have measured the particle size of Polycisplatin in distilled water by dynamic light scattering (DLS) method using a Malvern Zetasizer Nano-ZS analyzer. The average diameter of Polycisplatin nanoparticles was measured to be $18.6 \mathrm{~nm}$ as shown in Figure 1A and the PDI value was measured to be 0.39 . We have also scanned the TEM image of Polycisplatin, which appears as irregularly shaped nanoparticles as shown in Figure 1B.

\section{Biodistribution and Targeting Properties of Polycisplatin}

In order to evaluate the passive tumor-targeting properties of Polycisplatin, we have examined the timedependent organ distributions of Cy5.5-labeled Polycisplatin in the A549-tumor-bearing mice by measuring the fluorescence intensities of their major organs and plasma as described earlier. The fluorescence images of organs including liver, heart, lung, kidney, spleen, muscle, and tumor, as well as plasma, harvested from mice at 12, 24, and $48 \mathrm{~h}$ after injection are displayed in Figure 2.

As shown in Figure 3A, Cy-Polycisplatin was distributed dominantly in the tumor with the maximum value at $24 \mathrm{~h}$ after injection. The plasma concentration of $\mathrm{Cy}-$ Polycisplatin exhibited a time-dependent decrease, as shown in Figure 3B; however, strong fluorescence intensity was still detected at the last time point.

A quantitative diagram of the fluorescence intensity detected in each organ as well as the TTR (tumor-totissue ratio) values representing the tumor selectivity are displayed in Figure 3B. The highest TTR value was observed approximately 11 to $12 \mathrm{hr}$ post injection but decreased to 5-6 during $24-48 \mathrm{hr}$ post injection. Thus, the present Polycisplatin nanoparticles $(18.6 \mathrm{~nm})$ exhibited excellent tumor-targeting properties by EPR effect ${ }^{21,22}$ in spite of their relatively small particle size.

\section{In vitro Release of the Cisplatin Moiety $\left(\mathrm{NH}_{3}\right)_{2} \mathrm{Pt}(\mathrm{II})$ from Polycisplatin}

The time-dependent platinum contents released from Polycisplatin were measured using inductively coupled plasma atomic absorption spectrometry and displayed in Figure 4. At $\mathrm{pH} 7$ the accumulated amount of platinum released from Polycisplatin after 1 day was nearly $50 \%$ of the total loaded platinum and the total accumulated amount of released platinum for 2 weeks was approximately $60 \%$. The overall releasing pattern and total
A

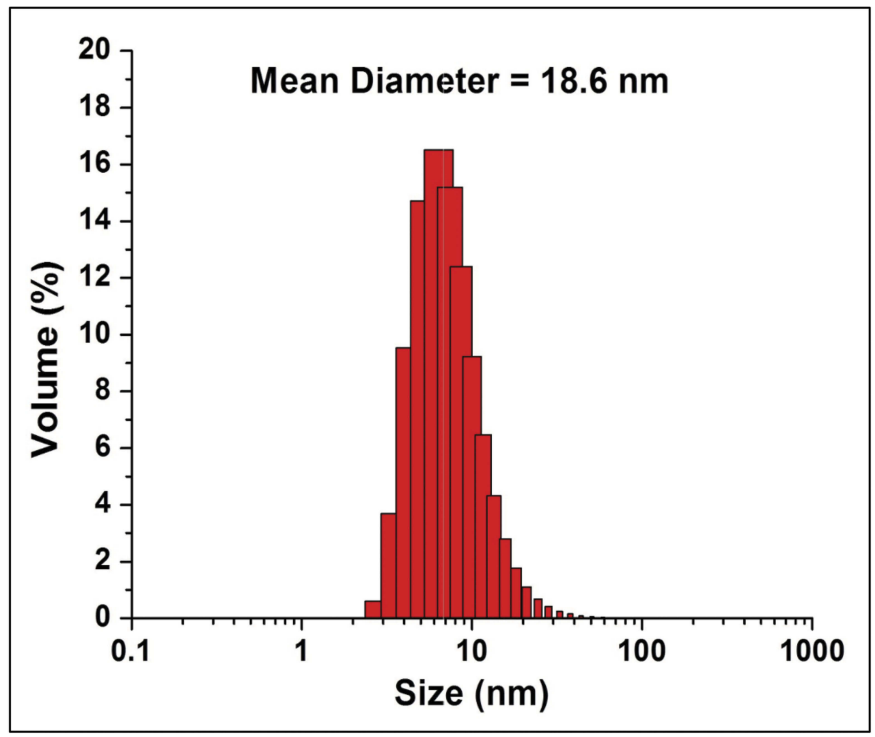

B

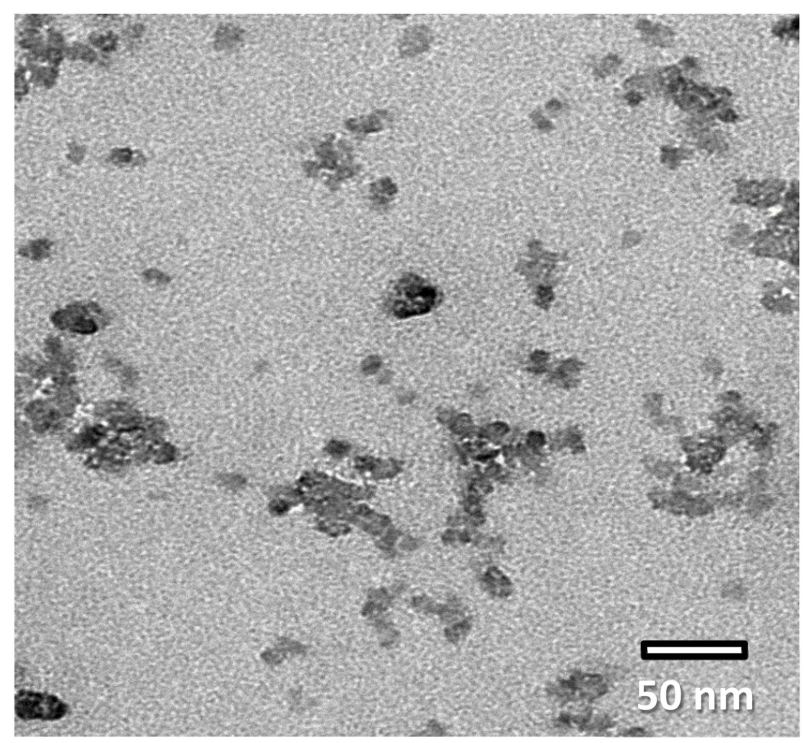

Figure I (A) Particle size distributions of Polycisplatin in saline. (B) TEM image of Polycisplatin in saline. 


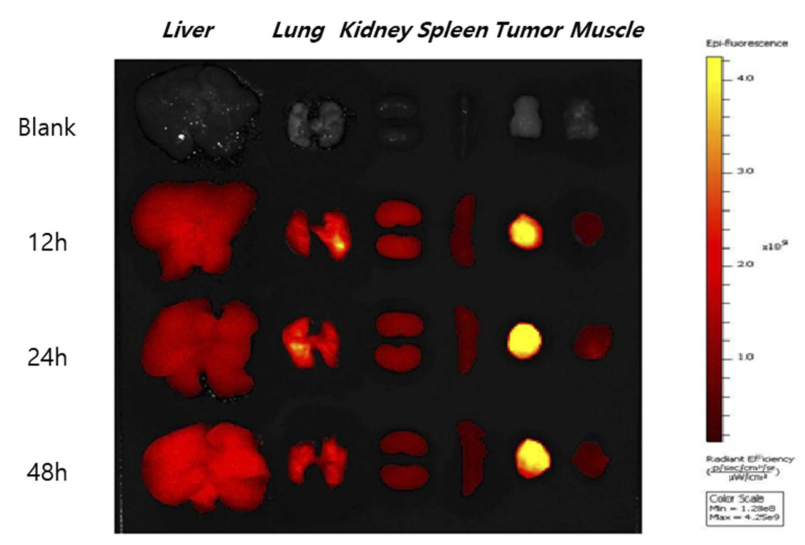

Figure 2 Time-dependent distributions of Cy-Polycisplatin in major organs of A549 lung tumor-bearing mouse.

accumulated amount of platinum released at $\mathrm{pH} 5$ are very similar to the above results at $\mathrm{pH} 7$. It is known that cisaconitic acid may be used as an acid-cleavable linker ${ }^{12}$ but it seems not working in the present system for an unclear reason. ${ }^{14,15}$ However, such a result is in consistent with the following xenograft results displaying that double dose of Polycisplatin exhibits almost the same efficacy at the double dose of cisplatin based on platinum metal.

\section{In vivo Antitumor Efficacy of Polycisplatin}

To estimate the antitumor efficacy of Polycisplatin compared with cisplatin as a positive control, we performed xenograft trials using gastric MKN-28 cell-derived tumorbearing nude mouse as described in detail in the experimental section. In this study, Polycisplatin and cisplatin as

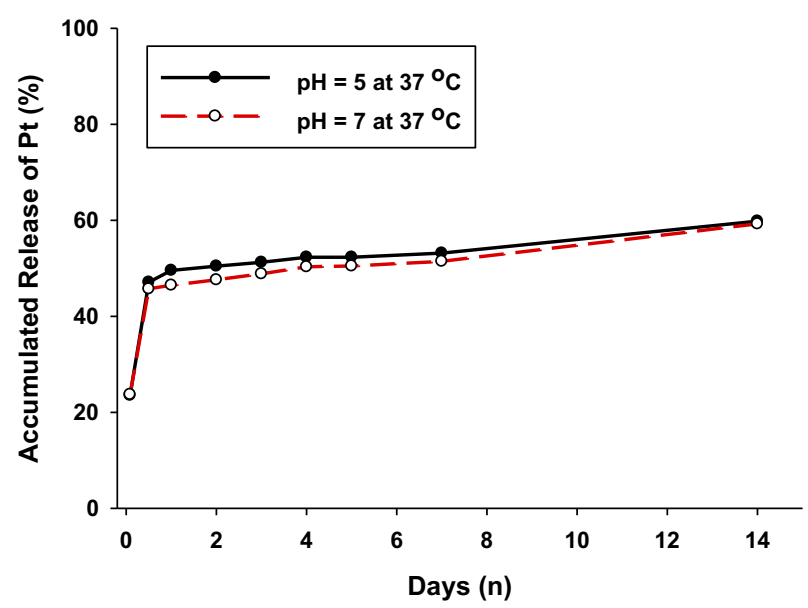

Figure 4 The release profiles of $\left(\mathrm{NH}_{3}\right)_{2} \mathrm{Pt}(\mathrm{II})$ moiety from Polycisplatin in $\mathrm{pH} 5.0$ and $\mathrm{pH} 7.0$ buffer solutions.

a reference were administered three times on days 1,5 , and 9 by intravenous injection at two different doses of $1.95 \mathrm{mg} \mathrm{Pt} / \mathrm{kg}$ and $3.9 \mathrm{mg} \mathrm{Pt} / \mathrm{kg}$ of Polycisplatin but reference cisplatin at a single dose of $1.95 \mathrm{mg} \mathrm{Pt} / \mathrm{kg}$, which is its maximum tolerate dose. To confirm the xenograft model, a negative control group was injected with saline solution. The tumor size and body weight of each mouse were measured every 3 or 4 days after injections. The results of the antitumor efficacy study and the body weight changes of the treated mice are displayed in Figures 5 and 6, respectively.

Tumor growth inhibition was observed in all drugtreated groups. Polycisplatin exhibited tumor suppression effect similar to that of cisplatin at the low dose of $1.95 \mathrm{mg}$
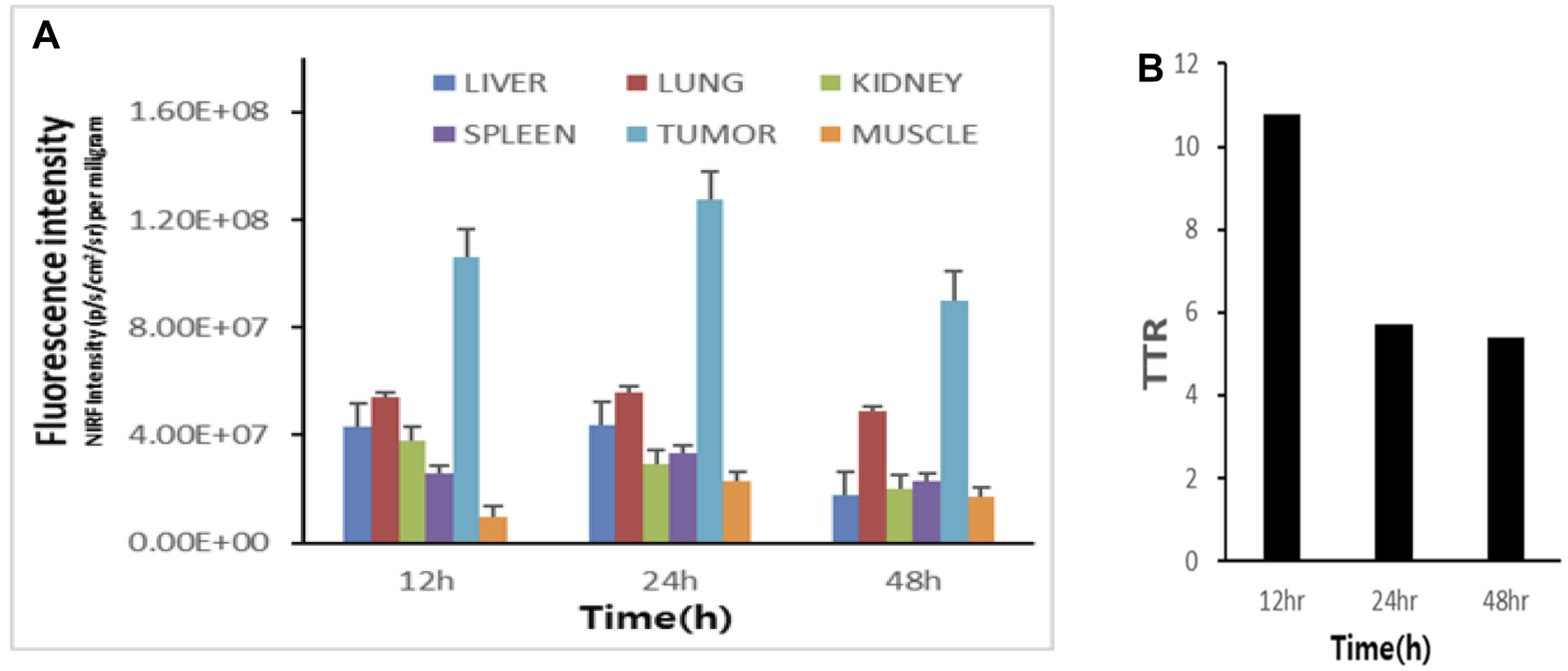

Figure 3 Time-dependent quantitative fluorescence intensities of Cy-Polycisplatin distributed in the major organs of A549 tumor-bearing mice (A) and tumor-to-tissue ratios (TTRs) (B). 


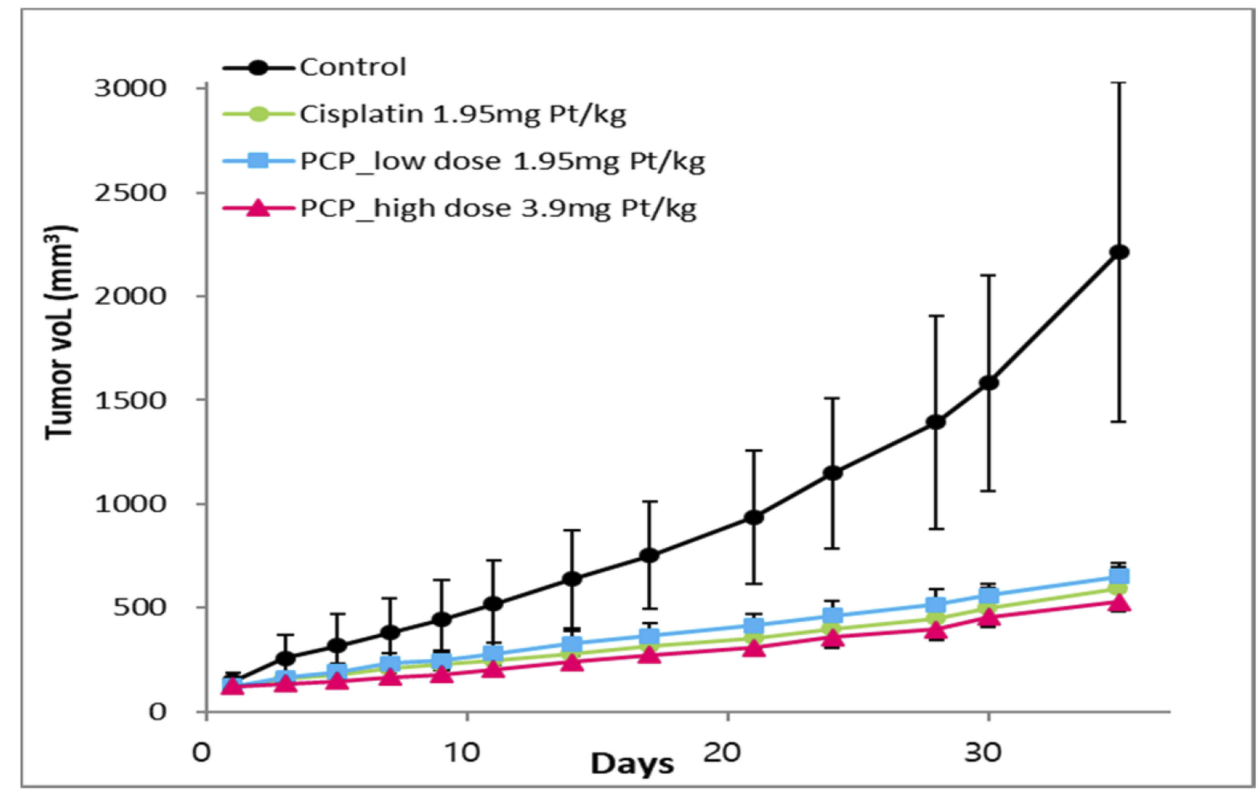

Figure 5 The results of xenograft trials of Polycisplatin and cisplatin as reference against the gastric MKN-28 cell line.

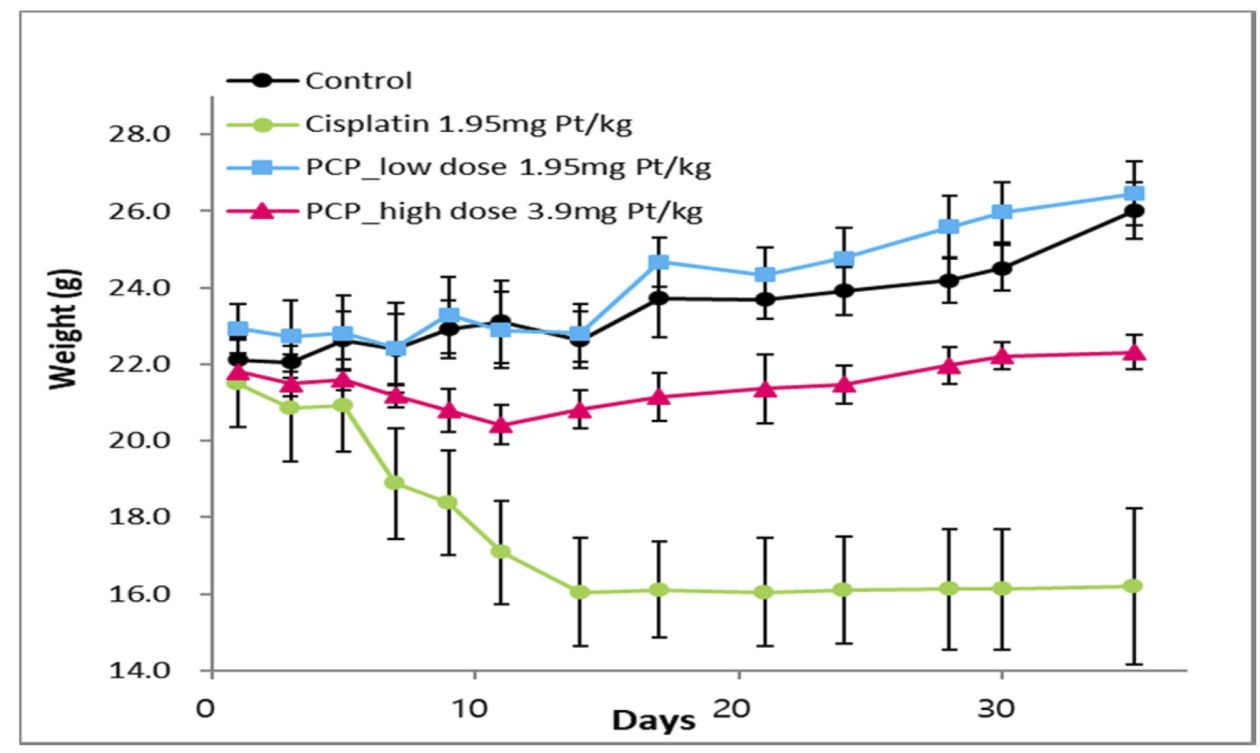

Figure 6 The body weight changes of the mice treated with Polycisplatin (PCP) and cisplatin as reference against the gastric MKN-28 cell line.

$\mathrm{Pt} / \mathrm{kg}$ but a little better effect than cisplatin at the higher dose. When cisplatin was injected into mice even at the low dose, the mean body weight was severely decreased by $25 \%$, while body weights of mice injected with Polycisplatin at the low dose of $1.95 \mathrm{mg} \mathrm{Pt} / \mathrm{kg}$ increased similarly to the saline group. The body weights of mice treated with the higher dose of $3.9 \mathrm{mg} \mathrm{Pt} / \mathrm{kg}$ of Polycisplatin were a little reduced but recovered immediately. The excellent antitumor efficacy and reduced systemic toxicity of Polycisplatin seem to be due to the stability of the nanoparticles formed from amphiphilic cisplatin-polyphosphazene conjugate molecules.

\section{Acute Toxicity of Polycisplatin}

ICR mice ( 5 weeks old) were treated by intravenous injection at increasing doses of 5,10,15 and $20 \mathrm{mg} \mathrm{Pt} / \mathrm{kg}$ of Polycisplatin and 6.5 and $13 \mathrm{mg} \mathrm{Pt} / \mathrm{kg}$ of cisplatin to compare their $\mathrm{LD}_{50}$ values. After intravenous injection to mice, their aspects and changes in body weight were observed carefully and recorded daily for 14 days. The 


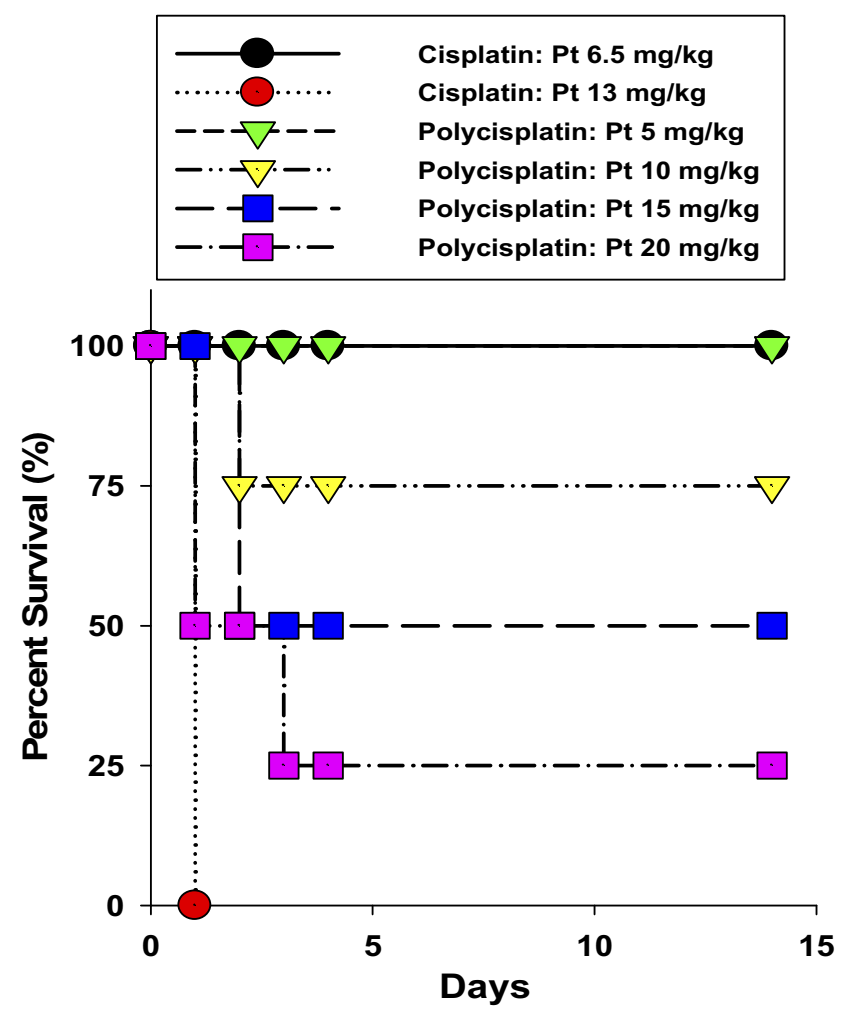

Figure 7 Results of the acute toxicity experiment of Polycisplatin compared with cisplatin.

survival rates of each group consisting of four mice treated at different dosages are presented in Figure 7.

In the case of cisplatin, all four mice survived at its lower dosage of $6.5 \mathrm{mg} \mathrm{Pt} / \mathrm{kg}$, but none of mice survived at the dose of $13 \mathrm{mg} \mathrm{Pt} / \mathrm{kg}$. According to the pharmaceutical paper, ${ }^{23}$ the $\mathrm{LD}_{50}$ value of cisplatin was estimated to be approximately $11 \mathrm{mg} / \mathrm{kg}$ equivalent to $7.12 \mathrm{mg} \mathrm{Pt} / \mathrm{kg}$. In case of Polycisplatin, no mortality was observed up to the dose of $2,25,100 \mathrm{mg} / \mathrm{kg}$ Polycisplatin. Only one of 4 mice survived at $200 \mathrm{mg} / \mathrm{kg}, 2$ of 4 mice survived at $300 \mathrm{mg} / \mathrm{kg}$ but all the mice treated with $400 \mathrm{mg} / \mathrm{kg}$ Polycisplatin died within several minutes after injection. Thus, $\mathrm{LD}_{50}$ value of Polycisplatin was determined to be about $300 \mathrm{mg} / \mathrm{kg}$ (Pt $15 \mathrm{mg} / \mathrm{kg}$ ) which is about 2 times higher compared with $\mathrm{LD}_{50}$ value of cisplatin, indicating that Polycisplatin has much lower acute toxicity compared to cisplatin.

\section{Nephrotoxicity of Polycisplatin and Cisplatin}

As shown in the above xenograft trials, there was a severe reduction in body weight of the mice treated with cisplatin even at the low dose of $1.95 \mathrm{mg} \mathrm{Pt} / \mathrm{kg}$ compared to other groups treated with Polycisplatin at the doses of 1.95 and $3.9 \mathrm{mg} \mathrm{Pt} / \mathrm{kg}$. It is well known that cisplatin critically damages the kidney ${ }^{3,24}$ and therefore, we have measured the kidney toxicity indicators such as kidney index, BUN and creatinine values as above-mentioned, and the results are illustrated in Figure 8.

Cisplatin-treated group (b) shows an increased kidney weight/body weight ratio, a marker for the body weight loss and increased renal size compared with both Polycisplatin-treated groups $(c)$ and $(d)$. In other words, Polycisplatin has significantly lower kidney toxicity compared with cisplatin. Also, increased BUN and creatinine values have been reported to be nephrotoxic. ${ }^{3,23}$ The BUN and creatinine values of cisplatin-treated group $(b)$ are much higher than that of the control group $(a)$ whereas Polycisplatin-treated groups $(c)$ and $(d)$ show very low
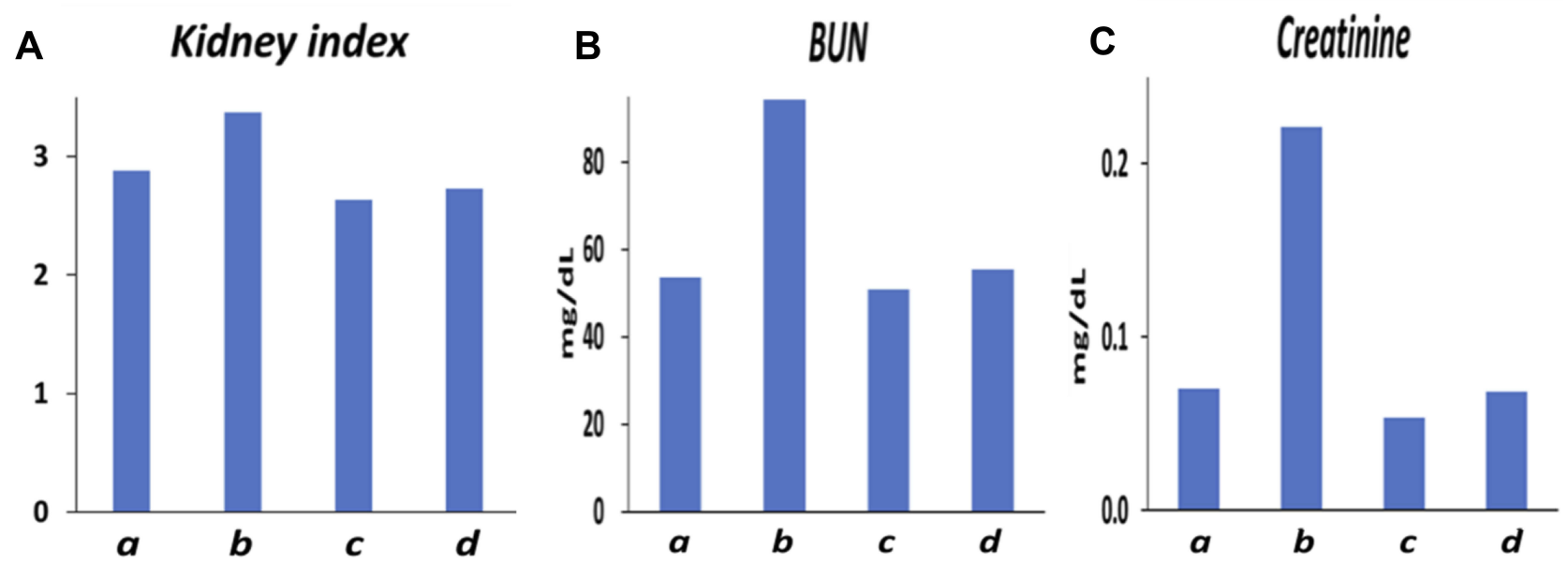

Figure 8 (A-C) Results of the measurements of kidney indicators to compare the kidney toxicities of mouse injected with saline (a), cisplatin at the dose of I.95 mg Pt/kg (b), Polycisplatin at the dose of $1.95 \mathrm{mg} \mathrm{Pt} / \mathrm{kg}$ (c), and $3.90 \mathrm{mg} \mathrm{Pt} / \mathrm{kg}(\mathrm{d})$. 
values similar to those of the control groups $(a)$. In conclusion, Polycisplatin exhibited much lower nephrotoxicity compared with cisplatin.

\section{Conclusion}

In this study, nanoparticular Polycisplatin was successfully prepared by conjugating cisplatin to a hydrophilic polyphosphazene carrier polymer using the acid-cleavable cisaconitic acid and thoroughly characterized by various techniques. In spite of relatively small size, polycisplatin nanoparticles exhibit excellent tumor-targeting properties by EPR effect. The xenograft trials exhibited excellent antitumor efficacy and reduced systemic toxicity of Polycisplatin. Polycisplatin exhibited a slightly less tumor suppression effect compared with cisplatin at the low dose of $1.95 \mathrm{mg} \mathrm{Pt} / \mathrm{kg}$ but a little better effect at higher dose of $3.9 \mathrm{mg} \mathrm{Pt} / \mathrm{kg}$. The body weights of mice treated with cisplatin was severely decreased even at the low dose, while body weights of mice injected with Polycisplatin did not show serious body weight decrease even at its double dose. Polycisplatin is much less nephrotoxic than cisplatin as shown by kidney indicators including kidney index, BUN, and creatinine values.

\section{Acknowledgments}

This research work was supported by National Research Foundation of Korea (NRF) grant funded by the Korean government (MEST) (2017R1A2B4007869).

\section{Disclosure}

The authors report no conflicts of interests in this work.

\section{References}

1. Reedijk J. New clues for platinum antitumor chemistry: kinetically controlled metal biding to DNA. Proc Natl Acad Sci USA. 2003;100:3611-3616. doi:10.1073/pnas.0737293100

2. Galanski M, Jakupec MA, Keppler BK. Update of the preclinical situation of anticancer platinum complexes: novel design strategies and innovative analytical approaches. Curr Med Chem. 2005;12:2075-2094. doi:10.2174/0929867054637626

3. McKeage MJ. Clinical toxicology of platinum-based cancer chemotherapeutic agents. In: Kelland LR, Farrell NP, editors. PlatinumBased Drugs in Cancer Therapy. Totowa: Human Press; 2000:251-275.

4. Brown R. Cisplatin resistance in ovarian cancer: mismatch repair and engagement of apoptosis. In: Kelland LR, Farrell NP, editors. Platinum-Based Drugs in Cancer Therapy. Totowa: Human Press; 2000:115-128.

5. Uchino H, Matsumura Y, Negishi T, et al. Cisplatin-incorporating polymeric micelles (NC-6004) can reduce nephrotoxicity and neurotoxicity of cisplatin in rats. Brit $J$ Cancer. 2005;93:678-687. doi:10.1038/sj.bjc.6602772
6. Xu P, Van Kirk EA, Murdoch WJ, et al. Anticancer efficacies of cisplatin releasing $\mathrm{pH}$-responsive nanoparticles. Biomacromolecules. 2006;7:829-835. doi:10.1021/bm050902y

7. Jadhav VB, Jun YJ, Song JH, et al. A novel micelle-encapsulated platinum(II) anticancer agent. J Control Release. 2010;147:144-150. doi:10.1016/j.jconrel.2010.07.101

8. Avaji PG, Joo HI, Park JH, et al. Synthesis and Properties of a new micellar polyphosphazene-platinum(II) conjugate drug. $J$ Inorg Biochem. 2014;140:45-52. doi:10.1016/j.jinorgbio.2014.06.014

9. Duan X, He C, Kron SJ, Lin W. Nanoparticle formulations of cisplatin for cancer therapy. WIREs Nanomed Nanobiotech. 2016;8:776-791. doi:10.1002/wnan. 1390

10. Haxtn KJ, Burt HM. Polymeric drug delivery of platinum-based anticancer agents. J Pharm Sci. 2009;98:2299-2316. doi:10.1002/ jps. 21611

11. Ma P, Xiao H, Li C, et al. Inorganic nanocarriers for platinum drug delivery. Mater Today. 2015;18:554-564. doi:10.1016/j.mattod.2015. 05.017

12. Yu H, Tang Z, Li M, et al. Cisplatin loaded poly(L-glutamic acid)-g-methoxy poly(ethylene glycol) complex nanoparticles for potential cancer therapy: preparation, In vitro and in vivo evaluation. J Biomed Nanotechnol. 2016;12:69-78. doi:10.1166/ jbn.2016.2152

13. Johnstone TC, Suntharalingam K, Lippard SJ. The next generation of platinum drugs: targeted $\mathrm{Pt}(\mathrm{II})$ agents, nanoparticle delivery, and Pt(IV) prodrugs. Chem Rev. 2016;116:3436-3486. doi:10.1021/acs. chemrev.5b00597

14. Kakinoki A, Kaneo Y, Ikeda Y, Tanaka T, Fujita K. Synthesis of poly (vinyl alcohol)-doxorubicin conjugates containing cis-aconityl acid cleavable bond and its isomer dependent doxorubicin release. Biol Pharm Bull. 2008;31:103-110. doi:10.1248/bpb.31.103

15. Yoo HS, Lee EA, Park TG. Doxorubicin-conjugated biodegradable polymeric micelles having acid-cleavable linkages. $J$ Control Release. 2002;82:17-27. doi:10.1016/S0168-3659(02)00088-3

16. Xue X, Hall MD, Zhang Q, Wang PC, Gottesman MM, Liang X-J. Nanoscale drug delivery platforms overcome platinum-based resistance in cancer cells due to abnormal membrane protein trafficking. ACS Nano. 2013;7:10452-10464. doi:10.1021/nn405004f

17. Singh MM, Szafran Z, Pike RM. Microscale synthesis of cis-diamminedihaloplatinum(II) and a corresponding trans isomer: A rapid and convenient method of preparing cisplatin - An anticancer drug. A laboratory experiment for inorganic and bioinorganic chemistry. J Chem Educ. 1990;67:A261-A262. doi:10.1021/ed067pA261

18. Sohn YS, Cho YH, Beak H, Jung OS. Synthesis and properties of low molecular weight polyphosphazenes. Macromolecules. 1995;28:75 66-7568. doi:10.1021/ma00126a039

19. Kaushik KH, Sripuram VK, Bedada S, Reddy NY, Priyadarshini GI, Devarakonda KR. A simple and sensitive validated HPLC method for quantitative determination of cisplatin in human plasma. Clin Res Regul Aff. 2010;27:1-6. doi:10.3109/10601330903490462

20. Avaji PG, Park JH, Lee HJ, et al. Design of a novel theranostic nanomedicine: synthesis and physicochemical properties of a biocompatible polyphosphazene-platinum(II) conjugate. Int J Nanomed. 2016;11:837-851.

21. Maeda H, Wu J, Sawa T, Matsumura Y, Hori K. Tumor vascular permeability and EPR effect in macromolecular therapeutics. J Control Release. 2000;65:271-284. doi:10.1016/S0168-3659(99)00248-5

22. Torchilin VP. Drug targeting. Eur J Pharm Sci. 2000;11:S81-S91. doi:10.1016/S0928-0987(00)00166-4

23. Barcellona PS, Campana A, Rossi V, Corradino C, Silvestrini B, Angelini F. A comparative study of acute toxicity of drugs used during anticancer therapy in healthy and tumor-bearing mice. Arch Toxicol Suppl. 1984;7:90-93.

24. Lee CK, Park KK, Hwang JK, Lee SK, Chung WY. Extract of Prunus persica Flesh improves chemotherapeutic efficacy and protects against nephrotoxicity in cisplatin-treated mice. Phytother Res. 2009;23:999-1005. doi:10.1002/ptr.2740 


\section{Publish your work in this journal}

The International Journal of Nanomedicine is an international, peerreviewed journal focusing on the application of nanotechnology in diagnostics, therapeutics, and drug delivery systems throughout the biomedical field. This journal is indexed on PubMed Central, MedLine, CAS, SciSearch ${ }^{\mathbb{B}}$, Current Contents ${ }^{\mathbb{B}} /$ Clinical Medicine, $^{2}$
Journal Citation Reports/Science Edition, EMBase, Scopus and the Elsevier Bibliographic databases. The manuscript management system is completely online and includes a very quick and fair peer-review system, which is all easy to use. Visit http://www.dovepress.com/ testimonials.php to read real quotes from published authors.

Submit your manuscript here: https://www.dovepress.com/international-journal-of-nanomedicine-journal 